Sudarić, T., Samardžija, L., Lončarić, R. (2020): Viticulture and wine as export potential of Croatia. Agriculture and Forestry, 66 (2): 57-66.

DOI: 10.17707/AgricultForest.66.2.06

\author{
Tihana SUDARIĆ, \\ Luka SAMARDŽIJA2, Ružica LONČARIĆl
}

\title{
VITICULTURE AND WINE AS EXPORT POTENTIAL OF CROATIA
}

\begin{abstract}
SUMMARY
This paper analyzes export potential of viticulture and winemaking in Republic of Croatia. Based on quantitative research methods applied by using Relative Trade Advantages (RTA) index, Export Competitiveness Index (XC), Comparative Advantage Index (RCA) and Relative Trade Advantage Index (RTA) in relation to EU countries. The 2015.-2016. study provided by the National Bureau of Statistics. The research results show negative macroeconomic indicators related to the potential of wine exports and lack of comparative advantage (0.25020853), negative trend of export competitiveness (0.753189), lack of export specialization (0.103778589) as well as negative trade advantage $(-2.0)$.
\end{abstract}

Keywords: viticulture, winemaking, exports, imports, index.

\section{INTRODUCTION}

Viticulture and winemaking of the Republic of Croatia can be presented as strategic activities of particular importance, because where the grapevine grows, it means a great deal of life and labor-intensive employment for the population (Milat, 2005). According to the data of the Croatian Chamber of Economy (2016), department responsible for agriculture, fisheries, forestry, wood and food industry in Republic of Croatia 1.5 million hectares of utilized agricultural land $54 \%$ refers to arable land and gardens, 5\% refers to orchards, vineyards and olive groves and $41 \%$ on permanent lawns. The importance of the food processing industry in relation to the total manufacturing industry is reflected in the fact that about a quarter of the indicator value relates to the food processing industry namely: number of persons employed (24\%), turnover (32\%), added value (26\%) and gross surplus (30\%). Food processing companies hold $16 \%$ share in the total

\footnotetext{
${ }^{1}$ Tihana Sudarić (corresponding author: tihana.sudaric@fazos.hr), Ružica Lončarić University of Josip Juraj Strossmayer in Osijek, Faculty of Agrobiotechnical Sciences Osijek, Department of Bioeconomics and Rural Development, Vladimira Preloga 1., Osijek, Republic of CROATIA.

${ }^{2}$ Luka Samardžija, University of Josip Juraj Strossmayer in Osijek, Faculty of Agrobiotechnical Sciences Osijek, PhD student, study program Agroeconomics, Vladimira Preloga 1., Osijek, Republic of CROATIA.

Paper presented at the GEA (Geo Eco-Eco Agro) International Conference 2020, Podgorica.

Notes: The authors declare that they have no conflicts of interest. Authorship Form signed online.

Received:07/04/2020

Accepted:20/05/2020
} 
processing industry (www.hgk.hr). Industry of agriculture, forestry and fisheries account for $3.7 \%$ of total GDP. Viticulture and winemaking in Croatia has a long tradition, a high level of production knowledge and producers experience which, in addition to favorable natural conditions and a developed market of demand, give stimulating conditions for sustainable production development. It is necessary to emphasize that there is also a high level of competition (domestic and foreign), relevant level of gray economy, and a high level of administrative legislation and, in comparison with other countries, a relatively small production capacity of manufacturers. Looking from quantity point of view Croatian vineyards and wine production, in relation to the international market, are consider small (Alpeza, 2014). However, according to Jelic Milkovic (2019), the wine industry has become more competitive than ever before.

With an annual wine production of 36 billion bottles worldwide and with more than a million different wine labels, winemakers are struggling to stand out and secure a position on a market. A large number of competitors and fierce competition among the winemakers characterizes bought Croatian and European wine markets. Therefore, according to the study (Del Vechio et al., 2017) buyers give primary importance to the quality of the product and if the domestic product is equal in this parameter with the foreign product, there is a strong motivation to purchase the product produced by the domestic industry. Wine is characterized as a highly complex product and the possibility of segmentation is extremely large (Samardzija et al., 2017). Considering all the above, aim of this paper is to analyze the export potential of viticulture and winemaking in Republic of Croatia according to quantitative methods for exploring comparative export advantages.

\section{MATERIAL AND METHODS}

Research in this paper is based on the analysis of secondary data sources provided by the National Bureau of Statistics (2015. /2016.), as well as data from the European Commission (EC, 2016). Analyzed data, quantitative methods for the research of comparative advantages and disadvantages of viticulture in the Republic of Croatia are applied based on the Relative Trade Advantages (RTA) index, Export Competitiveness Index (XC), Comparative Advantage Index (RCA) and Relative Index trade advantages (RTA) and relation to EU countries. Relative Trade Advantage (RTA) was developed by Vollrath (1991) and is calculated as the difference between relative export advantage (RXA) or Balassa index and relative import advantage (RMA):

$$
\text { RTA = RXA - RMA }
$$

where,

$$
\begin{aligned}
\operatorname{RXA} & =B=\left(X_{i j} / X_{i t}\right) /\left(X_{n j} / X_{n t}\right) ; \\
\operatorname{RMA} & =\left(M_{i j} / M_{i t}\right) /\left(M_{n j} / M_{n t}\right) ;
\end{aligned}
$$

$\mathrm{M}$ - import, i - a country; $\mathrm{j}$ - a commodity; $\mathrm{t}$ - a set of commodities; $\mathrm{n}$ - a set of countries. 
The positive value of the RTA index indicates comparative trade advantages, while negative values reveals comparative trade disadvantages. When RTA is greater than zero, then a comparative advantage is revealed, which means that a sector of the country is relatively more competitive in terms of trade (Cimpoies, L. 2017). Synthesis and descriptive methods have been applied in the interpretation of the results obtained and the formation of conclusions.

\section{RESULTS AND DISCUSSION}

Selected quantitative methods of analysis are used to understand the benefits of an economy in goods exchange process with the ultimate goal of meeting the stakeholder's needs. Initially assuming that economy resources are scarce and needs are unlimited, the analyzed theoretical framework operates within the production capabilities of each economy separately and opens opportunities to maximize benefits through exchange and specialization. The theoretical setting of Production Possibility Frontier (PPF) explains what are the maximum quantities of production that an economy can achieve with current technological knowledge and the available amount of resources.

PPF represents the output of goods and/or services available to the company at a given moment, opens options for decisions between production and exchange of goods using the calculation of opportunity cost. This theoretical model, although practical, is not always realistically usable. There are a large number of producers in the economy with different business plans, individual approaches to product management, and they do not have to (but can) participate in the international exchange of goods. Although reality is more complex for macroeconomic policy stakeholders, results of analysis and quantitative methods studies can stimulate and discourage specialization and exchange of agricultural products. In order to achieve as relevant research as possible, the analysis of secondary data sources makes the basis for applying quantitative methods to explore comparative export advantage through:

Revealed comparative advantage ( $R C A)$

This index measures comparative advantage in exports of goods "I" of country "Y". If the value is greater than 1 , then the analyzed country has pronounced comparative advantages in the export in specific goods. Conversely, if the value is less than 1 , then there is a clear lack of comparative advantage in the export of specific goods (Balassa, 1965). The author of this index is Béla Balassa, who (with the basic condition of the exception of the costs of production factors), by analyzing the results of export opportunities, sets comparative advantages among different economic systems. By comparing the advantages of two or more systems, one can see the potential for the exchange of goods. By analyzing the potential and adequately distributing the use of resources, in theory (even without increasing individual productivity) all participants can benefit. Eventually, the RCA index may show unreliable data due to the impact of the state on the economy, ie the impact of customs, incentives, export subsidies, which may affect the analysis of this index. 
Export Competitiveness Index $(\mathrm{XC})$

Export Competitiveness Index indicates a measure of the export performance of a product or group of products. The competitiveness of the economy is viewed through the analysis of the vital elements that make the economy productive. Purpose of this analysis is to compare across economies and the ultimate success is to increase the level of environmental quality, economic and social conditions to stimulate economic development. The export competitiveness of product "I" of country "Y" can be explained by the ratio of the share of the world market of country "Y" to product "I" in the observed period (t) with the ratio of share in the previous period. If the export competitiveness index is more than 1 , increasing export competitiveness is present. On the contrary, the realized value of less than 1 implies a negative trend of export competitiveness. The XC index can also be interpreted as the ratio of the growth rate of exports of products "I" to country "Y" and the rate of growth of products "I" to the world (Stojanov et al., 2011).

Export Specialization Index (ES)

Export Specialization Index (ES) is partly different from the Revealed comparative advantage (RCA), in which the denominator is usually measured by specific markets or partners. ES provides product information in the analyzed specialization in the country's export sector and is calculated as the ratio of the product's share of total country's exports to the share of that product in imports to specific markets or partners, rather than its share of world exports. ES is similar to RCA in that an index value of less than 1 indicates a comparative disadvantage and a value above 1 represents a specialization in this market (https://worldbank.org).

Relative Trade Advantage Index (RTA)

RTA is calculated as the difference between the Relative Export Advantage (RXA) (equivalent to the Balassa index) and the Relative Import Advantage (RMA). Results with an RTA index greater than 0 indicate the comparative advantage of the analyzed economy, while negative results indicate a lack of comparative advantage (Bezić et al., 2011).

Table 1 provides explanations for the RCA, XC, ES and RTA calculations in order to investigate the comparative export advantage. When applying quantitative methods, data for European Union countries were used instead of 'World' labels. Due to the inability to collect relevant and measurable data for World imports and exports, research is restricted to the European Union market only.

\section{Analysis of viticulture in Republic of Croatia}

According to the Ordinance on geographical areas of grapevine cultivation entire economic sector of viticulture and winemaking, from a territorialgeographical point of view (on a national level) is divided into 4 regions, 16 subregions and 66 appeals (NN 32/19 2019.) 
Table 1. Overview of quantitative methods for exploring comparative export advantage

\begin{tabular}{|c|c|c|c|}
\hline $\begin{array}{c}\text { Relative } \\
\text { Comparative } \\
\text { Advantage Index } \\
\text { (RCA) }\end{array}$ & $\begin{array}{c}\text { Export } \\
\text { Competitiveness Index } \\
\text { (XC) }\end{array}$ & $\begin{array}{l}\text { Export Specialization } \\
\text { Index } \\
\text { (ES) }\end{array}$ & $\begin{array}{l}\text { Relative Trade } \\
\text { Advantage Index } \\
\text { (RTA) }\end{array}$ \\
\hline $\begin{array}{c}\text { RCA }=[(\mathrm{Xij} / \\
\mathrm{Xnj}) /(\mathrm{Xit} / \mathrm{Xnt})]\end{array}$ & $\begin{array}{c}(\mathrm{XC} 0)=(\mathrm{Xij} / \mathrm{Xit}) \mathrm{t} / \\
(\mathrm{Xij} / \mathrm{Xit}) \mathrm{t}-1\end{array}$ & $\begin{array}{c}\mathrm{ES}=(\mathrm{xij} / \mathrm{Xit}) /(\mathrm{mkj} \\
/ \mathrm{Mkt})\end{array}$ & $\begin{array}{l}\text { RTA=RXA-RMA=( } \\
\text { Xij/Xit) / (Xnj/ Xnt) - } \\
\text { (Mij/Mit)/ (Mnj/Mnt) }\end{array}$ \\
\hline $\begin{array}{c}\text { Xij - export } \\
\text { country "I" } \\
\text { product "Y", } \\
\text { Xit - total export } \\
\text { of product "I", } \\
\text { Xnj - total export } \\
\text { of country "Y", } \\
\text { Xnt - total world } \\
\text { export. }\end{array}$ & $\begin{array}{l}\text { Xij - export country "I" } \\
\text { product "Y", } \\
\text { Xit - total export of } \\
\text { product "I", } \\
\text { t- time, } \\
\text { t-1- base time. }\end{array}$ & $\begin{array}{l}\text { Xij - export country } \\
\text { "I" product "Y”, } \\
\text { Xit - total export of } \\
\text { product "I", } \\
\text { mkj - the import } \\
\text { values of product "y" } \\
\text { in market "k", } \\
\text { mkt - total market } \\
\text { imports „,k“ }\end{array}$ & $\begin{array}{l}\text { RXAi: Relative export } \\
\text { comparative advantage } \\
\text { for product "I" } \\
\text { RMAi: Relative } \\
\text { import comparative } \\
\text { advantage for product } \\
\text { "I" } \\
\text { X: Total economy } \\
\text { exports } \\
\text { Xw: Total world } \\
\text { exports } \\
\text { M: Total economy } \\
\text { imports } \\
\text { Mw: Total world } \\
\text { imports }\end{array}$ \\
\hline
\end{tabular}

*Balassa, 1978.

According to the data of the Agency for Payments in Agriculture, Fisheries and Rural Development (2019), the total sum of agricultural parcels in the Republic of Croatia was 2.695.037 hectares, of which 1.113.520 hectares have been cultivated. There are 19.022.08 hectares of vineyards, 73.670 vineyards and 37.913 agricultural holdings under permanent vineyard plantations (www.apprrr.hr, 2019). The share of viticulture is $1.70 \%$ of the total agricultural area.

Season 2015/2016 was analysed as base year, in which according to the APPRRR, the total area of permanent vineyards was 20.709 ha (cumulative of all sub-regions combined), and in 2015, a there was total of 98.857 .66 tons of grapes was produced, from which it was obtained 690.787.39 liters of wine (www.apprrr.hr, 2016). An analysis of the available data shows that the total area under permanent vineyard planting has decreased. Area under vineyards was $3.48 \%$ lower than base year. The average grape yield was 4.7 tonnes/ha and 0.65 liters of wine was obtained from one $\mathrm{kg}$ of grapes. Despite many years of tradition and experience, the fact remains that the average utilization of production is relatively low (in line with the potential of maximum production). The utilization of production during grape cultivation has a direct impact on the quality of the finished product - wine.

Biodiversity of the vines in the territory of the Republic of Croatia is notable. By looking at the available data of APPRRR (2016) summing up units of area (ha) in agriculture at the level of the entire Republic of Croatia, the most 
represented grapevine variety was Graševina with $4,454.13$ ha (over $22 \%$ of total production), followed by Istrian Malvasia 1,635.63 ha (over 8\%) and Plavac Mali 1.562.63 ha (over 7\%). The three leading varieties make up over $38 \%$ of the total utilized agricultural area under the vineyard, while none of the other varieties exceed 1.000 ha (cumulatively on the entire territory of the Republic of Croatia).

In addition to the Law on Wines (NN 32/19), the market is regulated by regulations and inspection system of supervision. All administrative legal acts were adopted in accordance with the doctrine and practice of the European Union. Transparency of the production, promotion, consumption system (ban on sales to persons under 18 years), quality standards is responsibility of the competent legal authorities and the economy is regulated in detail. Macroeconomically speaking, it is the state that, through its institutions, must continually work to educate consumers about wine and to create the image of Croatia as a country of quality and diverse wine, both domestically and internationally. Only then will the foreign trade balance improve and exports become a strategic determinant of all winemakers in the Republic of Croatia (Kristić et al., 2012). According to information available from the Ministry of Agriculture, agricultural policy measures distinguish:

- direct grants,

- market measures and

- rural development measures.

Direct support includes measures under the Direct Payments Program regulated by the Common Agricultural Policy of the European Union and national measures for payments in extremely sensitive sectors and for the conservation of native and protected species and cultivars of agricultural plants (IEC). Direct payments under the Common Agricultural Policy of the European Union are an annual support to farmers' income. The direct payments program is financed by funds from the European Agricultural Guarantee Fund (EAGF) and by the State Budget of the Republic of Croatia for supplementary national direct payments (additional payment of direct payments from the state budget until 2022, when $100 \%$ of the amount will be financed by the EAGF (http://www.mps.hr/). According to the National Wine Sector Assistance Program 2014-2018, which is part of the sector specific support system under the Council Regulation (EC) establishing a common organization of the agricultural market and making specific provisions for certain agricultural products, the programs of promotion of the wine sector are recognized:

- promotion in third-country markets,

- restructuring and conversion of vineyards and

- investments in wineries and wine marketing.

Also, each county has the opportunity to adopt its own strategy for the development of viticulture and winemaking with the aim of maximizing capacity and utilizing resources, assuming that the strategy is adopted in accordance with national and EU strategies. In line with these strategies, the possibility of additional project financing opens with the funds from the common funds of the 
European Union. 26\% of the funds available for the development of Croatian agriculture have been contracted out of a total of EUR 2.38 billion available through the Rural Development Program (2014-2020) to the Republic of Croatia for the promotion of agricultural production and rural development (http://www.mps.hr). As a member of the European Union, the Republic of Croatia implements all obligations but have benefits of belonging to the Union. In accordance with the common regulations and norms, a customs system for the export and import of wine and grapes is implemented. In accordance with the relevant laws and standards, inspection standards are implemented and there is no particular protectionism against this production segment.

According to Kalazić et al. (2010), there are 1.032 registered winemakers in Croatia. The ten largest have a combined market share of $70 \%$ and the remaining 1.000 small winemakers hold $10 \%$ of the market. The average vineyard surface in Croatia is below 1 ha. About $14 \%$ of winemakers have a vineyard surface of up to 10 ha, and only 25 winemakers have a vineyard surface above 50 ha. Looking at the spectrum of legislation, economic entities operating in the agricultural production branch can be divided into family farm, craft, Trade Company, cooperative. In the Republic of Croatia, there are 39.429 holdings registered for grapevine cultivation. According to the data available from the Central Bureau of Statistics related to the balance of the wine market, from total wine consumption in 2015, 50.48\% came from domestic production, $15.49 \%$ from imports $34.03 \%$ from earlier stocks. According to the results the majority of producers in the region use international varieties for production of wine (Pajović-Šćepanović et al., 2017).

Table 2. Foreign Trade Balance of Wine 2015. /2016.

\begin{tabular}{|c|c|c|c|c|c|c|c|}
\hline & & \multicolumn{2}{|c|}{ Import 2016.} & \multicolumn{2}{|c|}{ Import 2015.} & Index & \\
\hline CT & Product & ton & EUR & ton & EUR & 16./15. EUR & \\
\hline \multirow[t]{2}{*}{2204} & $\begin{array}{c}\text { Fresh } \\
\text { grape wine }\end{array}$ & 30.908 & 30.769 .499 & 28.920 & $\begin{array}{l}29.006 .7 \\
54\end{array}$ & 106 & \\
\hline & & \multicolumn{2}{|c|}{ Export 2016.} & \multicolumn{2}{|c|}{ Export 2015.} & Index & \\
\hline CT & Product & ton & EUR & ton & EUR & 16./15. EUR & \\
\hline 2204 & $\begin{array}{c}\text { Fresh } \\
\text { grape wine } \\
\end{array}$ & 3.608 & 10.531 .686 & 4.932 & \begin{tabular}{|l}
12.398 .3 \\
28 \\
\end{tabular} & 85 & \\
\hline CT & Product & \multicolumn{2}{|c|}{ Import 2016.} & \multicolumn{2}{|c|}{ Export 2016.} & & $\begin{array}{c}\text { Import over } \\
\text { export }\end{array}$ \\
\hline 2204 & $\begin{array}{c}\text { Fresh } \\
\text { grape wine }\end{array}$ & 30.908 & 30.769 .499 & 3.608 & $\begin{array}{l}10.531 .6 \\
86\end{array}$ & -20.237 .813 & $34 \%$ \\
\hline
\end{tabular}

Source: Croatian Chamber of Economy 2015. /2016. www.hgk.hr

According to data available from the Croatian Chamber of Economy related to the import and export of wine in the 2015/2016 season a negative balance is evident. The natural conditions, the level of knowledge and experience of the producers as well as the quality of the final products are not in question, but the presence of Croatian producers' wines on the international markets is. Although the export/import ratio was only $34 \%$. According to research by Kristić 
et al. (2012) small winemakers, unable to create their own brand or invest heavily in promotion, and burdened with illiquidity, large inventories and questionable placement, maneuvering with price and especially emphasizing country of origin remains the only choice in the fight against fierce competition. An important item that is not included in the mentioned balance sheet is the fact that part of the wine placement uses sales channels through catering establishments that operate within the tourist offer of the Republic of Croatia and they (especially those operating on the coast) market their products to guests from abroad. Tourism is a very important source of foreign exchange, which is why it is classified as a favored export branch. It is a significant fact that this foreign exchange inflow is not accompanied by the export of goods across borders, so this type of export is called "invisible export" or "silent export" and "on-site export". Instead of exporting goods, the consumer or tourist whose consumption in the destination is the basis of foreign exchange inflow is here imported (Bošković, 2009).

According to EUROSTAT (https: ec.europa.eu, 2016), the countries of France, Italy, Spain, Austria, Hungary, Bulgaria, Slovenia and Luxembourg have a positive foreign trade balance of wine. Like most EU Member States, the Republic of Croatia has a negative balance.

Indicators of export potential of wine of the Republic of Croatia

Table 3 shows the wine production of the Republic of Croatia compared to the EU member states according to the quantitative macroeconomic indices RCA, $\mathrm{XC}, \mathrm{ES}$ and RTA.

Table 3. Indicators of export potential of wine in the Republic of Croatia

\begin{tabular}{|c|c|c|c|c|c|c|c|}
\hline \multicolumn{2}{|r|}{ RCA } & \multicolumn{2}{|r|}{$\mathrm{XC}$} & \multicolumn{2}{|r|}{ ES } & \multicolumn{2}{|r|}{ RTA } \\
\hline Xij & $6.252,00$ & $\mathrm{Xij}-\mathrm{t}$ & 6252,00 & $\mathrm{Xij}$ & $6.252,00$ & Mij & $15.711,00$ \\
\hline Xit & $10.120 .180,00$ & Xit -t & 10120180,00 & Xit & $10.120 .180,00$ & Mit & $2.639 .252,00$ \\
\hline Xnj & $4.306,60$ & $\mathrm{Xij}-\mathrm{t}-1$ & 8049 & Mkj & $15.711,00$ & Mnj & $4.566,0$ \\
\hline Xnt & $1.744 .238,50$ & Xit -t-1 & 9813302 & Mkj & $2.639 .252,00$ & Mnt & $1.712 .713,1$ \\
\hline Total: & 0,250208503 & Total: & 0,753189 & Total: & 0,103778589 & Total: & $-2,0$ \\
\hline
\end{tabular}

Source: authors according to the National Bureau of Statistics, 2016

Relative Comparative Advantage Index (RCA), which measures the comparative advantage in the export of wines produced in the Republic of Croatia, showed a value of 0.25020853 . From the above, it is evident that this value is less than 1 and it can be concluded that there is a clear lack of comparative advantage in the export of the analyzed product.

Export Competitiveness Index (XC) indicating a measure of the export performance of a product or group of products (in this case, wine) showed a value of 0.753189 . The analysis of the export competitiveness of wine products of the Republic of Croatia can be explained as the ratio of the share on the European market of Croatia with the wine product in the observed period 2015/2016 with the ratio of the share in the previous period export ineffective. The value obtained by calculating all parameters is less than 1 , implying a negative trend in export 
competitiveness. It is possible to make an indicative conclusion that the ratio of the growth rate of export of wine produced in Croatia to the rate of growth of wine products on the European market is inadequate in this case.

Export Specialization Index (ES) is 0.103778589 indicates a comparative lack of specialization in the European market. In the analyzed specialization, the export spectrum of Croatia in the wine segment (calculated as the ratio of the share of wine in total country exports) relative to the share of that wine in imports into the European Union markets.

Relative Trade Preference Index (RTA) is -2.0. The negative RTA index indicates the lack of comparative advantage of wine production in the Republic of Croatia compared to the production of wines of other EU Member States. is -2.0. The negative RTA index indicates the lack of comparative advantage of wine production in the Republic of Croatia compared to the production of wines of other EU Member States.

\section{CONCLUSIONS}

Viticulture and winemaking in the Republic of Croatia is characterized by a long tradition, a high level of knowledge and experience of producers as well as favorable natural conditions. Wine is undoubtedly a strategic agricultural food product of the Republic of Croatia, and the total domestic consumption of wine is about 1002000 hectoliters, while the self-sufficiency of wine production is $80 \%$.

Although the Republic of Croatia is an interesting market for an increasing number of importers, it has the potential to export individual wines, ie grape varieties (Graševina, Istrian Malvasia, Plavac Mali etc.). The results of the survey show production of wine of Republic of Croatia, in comparison with the EU member states, according to the quantitative macroeconomic indices RCA, XC, ES and RTA. The input variables for measurable comparative advantage in the export of wines produced in the Republic of Croatia are based on secondary data sources (CBS, APPPR, HGK, MP). The obtained results induce negative macroeconomic indices related to the potential of wine exports, that is, to the European Union market. The conclusions obtained from the analysis and processing of the available secondary data are only indicative and can be used as guidance for improving the strategy of economic activity of the export potential of viticulture and winemaking in the Republic of Croatia.

\section{REFERENCES}

Alpeza I, Prša I, Mihaljević B. 2014. Viticulture and Enology of the Republic of Croatia in the World, Journal of Plant Protection, 37, 4; 6-13.

Balassa B. 1965. Trade Liberalization and Revealed Comparative Advantage, The Manchester School of Economic and Social Studies, Vol. 119, 93-123.

Balassa B. 1978. Export and economic growth, Journal of Development Economics, North-Holland Publishing Company, No. 5, pp. 203.

Bezić H, Cerović Lj, Galović T. 2011. Changes in the competitive advantages of Croatia's manufacturing industry, Zbornik radova, Ekonomski fakultet u Rijeci, Vol. 29 (2), 465-487. 
Bošković T. 2009. Turizam kao faktor privrednog razvoja, Visoka poslovna škola strukovnih studija, Škola biznisa, br. 2/2009, Novi Sad, 23-28.

Cimpoies L. 2017. The competitiveness of agricultural foreign trade commodities: the case of the Republic of Moldova, 52nd Croatian and 12th International Symposium on Agriculture, University of Zagreb, Faculty of Agriculture, Dubrovnik, 129-133.

Del Vechio M, Samardžija L, Kuzmanović S. 2017. Analiza percepcije odabira između domaćih i inozemnih vina istog cjenovnog razreda, 52nd Croatian and 12th International Symposium on Agriculture, University of Zagreb, Faculty of Agriculture, Dubrovnik, 136-139.

Jelić Milković S. 2019. Market orientation and entrepreneurial effect of winemakers, Ekonomski Vjesnik; Osijek Vol. 32, Iss. 1, 83-92.

Kalazić Z, Leko-Šimić M, Horvat J. 2010. Wine market segmentation in continental Croatia, Journal of Food Products Marketing, Vol. 16, No. 3, 325-335. 6.

Kristić J, Sudarić T, Lončarić R. 2012. Zemlja podrijetla vina kao determinirajući čimbenik pri odlučivanju o kupnji, in Pospišil, M. (Ed.), 47th Croatian and 7th International Symposium on Agriculture, University of Zagreb, Faculty of Agriculture, Opatija, 198-201.

Milat V. 2005. Stanje u vinogradarstvu i vinarstvu Republike Hrvatske, Glasnik zaštite bilja, Vol. 28, No. 6, 5-15.

Pajović-Šćepanović R., Savković S., Raičević D., Popović T. 2017. Characteristics of the Montenegrin rose wine. Agriculture and Forestry, 63 (4): 131-139. DOI:10.17707/AgricultForest.63.4.15

Samardžija L, Soukup D., Kuzmanović S. 2017. Analysis of buying habits - wine segment, International Journal - VALLIS AUREA, Vol. 3, No. 2, 103-110.

Stojanov D, Bezić H, Galović T. 2011. Izvozna konkurentnost Primorsko -goranske županije, Ekonomski vjesnik, Ekonomski fakultet u Osijeku. XXIV, 1; 33-46, UDK 339.137. 497-537.

Vollrath T L. 1991. A theoretical evaluation of alternative trade intensity measures of revealed comparative advantage, Weltwirtschaftliches Archiv, Volume 127(2), 265-280.

Wine Law NN 32/19 in force since 01.04.2019.

https://www.zakon.hr/z/277/Zakon-o-vinu; (accessed January 21 2019)

https://wits.worldbank.org/wits/wits/witshelp/Content/Utilities/e1.trade_indicators.htm

(accessed September 05, 2016).

https://www.hgk.hr/documents/republikahrvatska2016hrweb5824783267fa1.pdf

(accessed September 07, 2016).

https://narodne-novine.nn.hr/clanci/sluzbeni/2012_07_74_1723.html

(accessed September 07, 2016).

Commission Européenne; (2016) Direction générale de l'agriculture et du développement rural Direction C. Économie des marchés agricoles (et OCM) Comext Wine Trade results

https://ec.europa.eu/agriculture/sites/agriculture/files/wine/statistics/wine-trade-

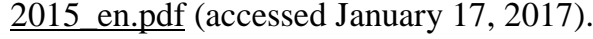

